\title{
SILVER RECOVERY FROM END-OF-LIFE PHOTOVOLTAIC PANELS
}

\author{
Larisse Suzy Silva de Oliveira ${ }^{1}$, Maria Tereza Weitzel Dias Carneiro Lima ${ }^{2}$, Luciana Harue \\ Yamane ${ }^{1}$ and Renato Ribeiro Siman ${ }^{1, *}$ \\ 1 Department of Environmental Engineering, Federal University of Espírito Santo, Fernando Ferrari Avenue 514, Goiabeiras, Vitória, \\ 29075-910, Brazil \\ ${ }^{2}$ Department of Chemistry, Federal University of Espírito Santo, Fernando Ferrari Avenue 514, Goiabeiras, Vitória, 29075-910, Brazil
}

Article Info:

Received:

11 November 2019

Revised:

17 February 2020

Accepted:

24 February 2020

Available online:

31 March 2020

Keywords:

Photovoltaic panel

Silver recovery

Hydrometallurgical

E-waste

Recycling

\begin{abstract}
The growth of the photovoltaic sector has stood out among renewable sources of energy, due to technological innovations that have brought about cost reductions. Thus, this paper aimed to analyze the technical feasibility of silver recovery from photovoltaic cells using acid leaching, followed by an evaluation of the chemical and electrochemical precipitation processes to analyze their efficiencies. As a primary objective of this work, the gravimetric composition and the metal concentration (Ag, $\mathrm{Al}, \mathrm{Pb}, \mathrm{Cu}$, and $\mathrm{Fe}$ ) in the photovoltaic cells were first determined, developing the basis for future research on photovoltaic panels recycling Subsequently, the influence of $\mathrm{HNO}_{3}$ concentration (1-10 mol/L), temperature $\left(25-60^{\circ} \mathrm{C}\right)$, and reaction time were evaluated. A new research application used a statistical tool, the Central Composite Rotational Design (CCRD), as well as samples of different brands and models of photovoltaic panels, in order to ensure the experimental validity. As a highlight, the analysis of the composition of the photovoltaic cells, applying the $\mathrm{HNO}_{3}$ leaching, showed that up to $6.87 \mathrm{~kg}$ of silver can be recovered per ton of photovoltaic cells. It was possible to solubilize $100 \%$ of the silver contained in the photovoltaic cells using the optimal parameters. Silver precipitation by addition of $\mathrm{HCl}$ and $\mathrm{Na}_{2} \mathrm{CO}_{3}$, as well as electroprecipitation, made it possible to extract more than $99 \%$ of silver in solution, being a primary novelty of this study. Therefore, the studied pathway allowed for the recovery of $99.98 \%$ of the silver present in the photovoltaic cells.
\end{abstract}

\section{INTRODUCTION}

The development of alternative energy sources has been explored in order to increase energy supply and to replace or reduce the exploitation of non-renewable sources. Among the renewable sources of energy, solar energy from photovoltaic panels is one of the most used and efficient methods (Europe, 2018). It is estimated that an installed power of $26.7 \mathrm{MW}$ allows for saving about 560,700 $\mathrm{t}$ of Carbon dioxide equivalent ( $\mathrm{tCO}_{2}$ eq) during the lifetime of the photovoltaic system, as an alternate to fossil fuels. If the photovoltaic panels were recycled instead of being landfilled, it can additionally save about $1600-2400 \mathrm{tCO}_{2}$ eq. (D'Adamo et al., 2017).

Rapid development of the photovoltaic industry has presented a global challenge with respect to the recycling of valuable components from end-of-life photovoltaic panels, due to the approximate 30 year lifespan of these panels (Song et al., 2020).

It is estimated that by the year 2050, 78 million tons of photovoltaic panels will need to be disposed of around the world, but information about their destinations (recy- cling) and final disposal are still scarce (Weckend, Wade, \& Heath, 2016). According to Domínguez \& Geyer (2019), there will be 800 thousand metric tons $(\mathrm{Mt})$ of end-of-life photovoltaic panels in need of disposal between 2030 and 2060 in the United States alone. Table 1 shows some estimatives of photovoltaic panels waste.

Due to this potential generation of end-of-life photovoltaic panels in the coming years, some studies evaluating different recycling processes and routes have been conducted. They have especially focused on crystalline silicon panels, representing $85-90 \%$ of the market due to low prices and mature manufacturing technology (Song et al., 2020).

Silicon photovoltaic panels are composed of an aluminum frame, tempered glass, a silicon photovoltaic cell with metal filaments that are wrapped in two layers of encapsulating material, and a backsheet (Tammaro et al., 2016). The main metals present in photovoltaic panels are lead, copper, alluminum, and silver (Dias et al., 2016). The composition of a silicon photovoltaic panel (a) and its cell (b) is shown in Figure 1. 
TABLE 1: Estimates of photovoltaic panel waste generation.

\begin{tabular}{|c|c|c|c|}
\hline Area & Year & Tonnes & Reference \\
\hline \multirow{6}{*}{ World } & 2030 & 8 millions & Weckend et al. (2016) \\
\hline & 2030 & 1.7 millions & Gangwar et al. (2019) \\
\hline & 2035 & 1 million & $\begin{array}{l}\text { International Energy Agency } \\
(2013)\end{array}$ \\
\hline & 2038 & 1.9 millions & Paiano (2015) \\
\hline & 2050 & 60 millions & Gangwar et al. (2019) \\
\hline & 2050 & 78 millions & Weckend et al., 2016 \\
\hline Czech republic & 2025 & 545 thousand & Kumar \& Sarkan (2013) \\
\hline Europe & 2020 & 18 thousand & Larsen (2009) \\
\hline Italy & 2050 & 8 millions & Paiano (2015) \\
\hline EUA & 2050 & 9.57 millions & Monier \& Hestin (2011) \\
\hline EUA & 2060 & 9.8 millions & Domínguez \& Geyer (2019) \\
\hline Spain & 2030 & 100 thousand & $\begin{array}{l}\text { Santos \& Alonso-García } \\
(2018)\end{array}$ \\
\hline Spain & 2050 & 700 thousand & $\begin{array}{l}\text { Santos \& Alonso-García } \\
(2018)\end{array}$ \\
\hline
\end{tabular}

Materials such as aluminum, silicon, gold, steel, and copper represent around $75 \%$ of the total value of a photovoltaic panel system (including inverters, transformers, cabling, and mouting), but Figure 1 shows the composition for only the photovoltaic panel and cell (Domínguez \& Geyer, 2019).

Although several studies have been carried out with the aim of recovering silicon, aluminum, or glass in photovoltaic panels (Azeumo et al., 2019; Dias et al., 2017; Fiandra et al., 2019), exploration of silver extraction methods is of more recent interest, and there is still a need to improve the feasibility of processes (Kuczyńska-Łażewska et al., 2018). Additionally, Apergis \& Apergis (2019) analyzed the role of solar energy production in driving silver prices, pointing out that higher silver prices due to decreases in supply could negatively affect promotion of solar energy sources and their sustainable growth.

In this sense, Deng, Chang, Ouyang, \& Chong (2019) suggested that value recovery, including recovering intact silicon wafers and silver, should be a pursued in order to make high-value recycling more attractive, in addition to current mass recovery of glass and the aluminium frame carried out by recyclers. Dias et al. (2016) studied the extraction of silver from photovoltaic modules via the solubilization of silver in nitric acid. This process was followed by precipitation with addition of sodium chloride, where recovery of $94 \%$ of silver was achieved. In a second test, the samples were submitted to pyrolysis prior to the acid leaching process, and silver recovery was $92 \%$.

Kuczyńska-Łażewska et al. (2018) analyzed the silver and aluminium extraction from the solar cell using acid and basic leaching process with $\mathrm{HNO}_{3}$ and $\mathrm{NaOH}$ at different concentrations and temperatures. They concluded that there is no justified need for highly corrosive substances, such as hydrofluoric acid, strong oxidising agents, or temperatures above $60^{\circ} \mathrm{C}$, except for removal of metals from the solar cell surface.

Moreover, silver concentration was investigated by Song et al. (2020) using high voltage fragmentation and by Nevala et al. (2019) using electro-hydraulic fragmentation as a substitutes for mechanical methods to dismantle endof-life photovoltaic panels. This was done to concentrate valuable metals on specific particle size fractions in order to facilitate the separation and recovery of metals.

Therefore, it is possible to use several techniques to recycle and recover the metals present in photovoltaic panels, and it is necessary to evaluate technical, economic, and environmental aspects to choose the routes to be used.

In the review performed by Padoan, Altimari, \& Pagnanelli (2019) comparing solutions proposed over the past two decades to recycle photovoltaic panels, it was highlighted that energy consumption in a recycling process is less than that spent in the manufacturing of a new panel, and recovery techniques are in constant development.

Del Pero et al. (2019) performed a Life Cycle Assessment of a recycling process (mobile pilot scale) of solar panels waste. The investigation of all Life Cycle stages showed that recycling from different material fractions (aluminum, glass, copper, silicon, and plastics) allows for achieving great environmental benefits, due to avoided production of new materials and energy. Also, according to (a)

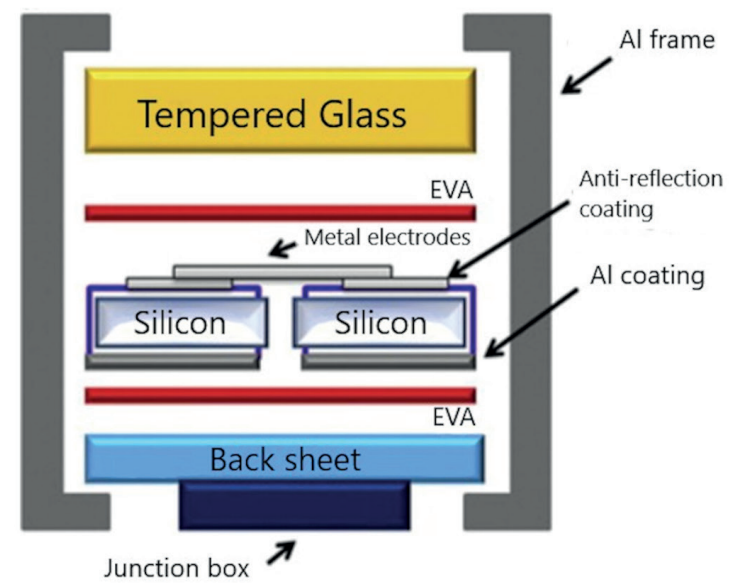

(b)

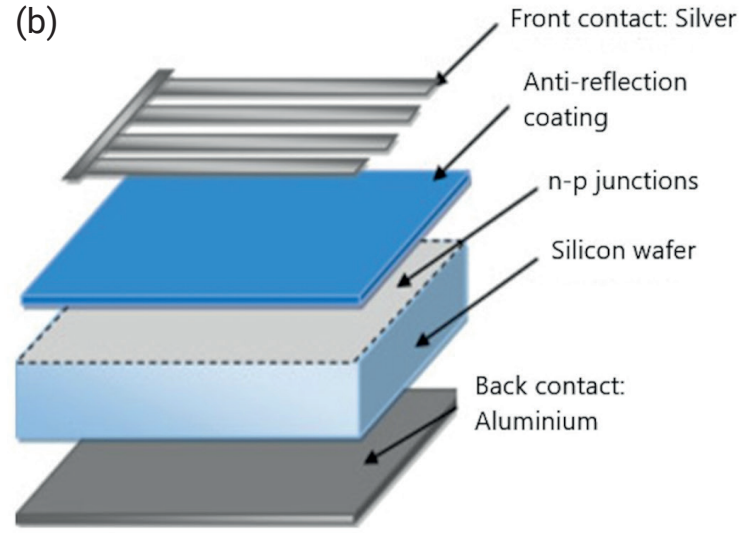

FIGURE 1: Composition of a panel (a) and a silicon photovoltaic cell (b) of first generation. Adapted from KANG et al. (2012); So; Yu (2015). Legend: EVA - ethylene-vinyl acetate. 
Sica et al.(2018), the photovoltaic sector may be one of the biggest contributors to the circular economy, applying the metaphor of natural systems to the production of goods and services. They estimated that about 42 new photovoltaic panels can be produced by the recycling of 100 used photovoltaic panels.

The photovoltaic sector is trying to improve photovoltaic panels design from an ecological perspective. Some producers are investing in research to find less hazardous materials and production processes with low environmental impact in order to reduce risks for the human health and environment (Sica et al., 2018).

In this sense, the present study evaluates the feasibility of a novel route to selectively extract and recover the silver from photovoltaic cells by nitric acid leaching, followed by selective silver precipitation (chemical and electrochemical). Comparison of silver precipitation processes by addition of $\mathrm{HCl}$ and electroprecipitation as the last step of the proposed route is the primary study novelty.

Although few studies have used electrochemical or chemical precipitation to recover silver from photovoltaic panels (Lee, et al., 2013; Yousef et al., 2019), the present study contributes an analysis of three different models of photovoltaic panels, using three units of each model and three samples of each unit (triplicate). With this number of samples and using statistic tools in a Central Composite Rotational Design (CCRD) to generate response surfaces and perform analysis of variance (ANOVA), the obtained results are more consistent and reliable.

Progress in the reuse processes for the photovoltaic panels components will allow for the minimization of environmental impacts generated from its inadequate disposal, such as the reduction of carbon footprint, and also to reduce the consumption of resources from primary sources (Yousef et al., 2019).

\section{MATERIALS AND METHODS}

The experimental procedure began with the experimental design and with the collection of the end-of-life photo- voltaic panels. Afterwards, the gravimetric composition of the photovoltaic panels (STEP 1) was determined. The photovoltaic cells were removed by manual and thermal separation, followed by the characterization stage (STEP 2) and acid leaching tests (STEPS 3 and 4). Finally, the recovery of silver in solution was performed using chemical and electrochemical precipitation (STEP 5).

\subsection{End-of-life photovoltaic panels}

Three photovoltaic panels were donated by the Solar Brasil Tecnologia \& Energia Fotovoltaica Ltda (São Paulo, Brazil) company, presenting damaged protection glass.

In order to allow for comparison of the results, 6 photovoltaic panels of two different models ( 3 of each) were acquired. In this way, 9 photovoltaic panels (three models) formed of polycrystalline silicon (1st generation) were analyzed. Table 2 shows the main characteristics of the panels, and Figure 2 illustrates an example of each photovoltaic panel model used in the research.

\subsection{Step 1 - Gravimetric composition of end-of-life photovoltaic panels}

The photovoltaic panels were individually weighed on a balance (brand Marte/50 kg scale). Using manual separation, each model of photovoltaic panels was analyzed for the percentages of aluminum, glass, photovoltaic cells, and polymeric material that compose them. To do so, photovoltaic cell size portions of each photovoltaic panels were sampled.

Using the average composition of the photovoltaic cells analyzed, the ratio of glass and polymer was calculated to estimate the weight of the panel edges that did not contain photovoltaic cells. The weight of the photovoltaic cells was subtracted from the photovoltaic panel total, and the proportions obtained between polymers and glass were used to estimate the weight of these components in areas where there were no photovoltaic cells.

To separate the glass, polymers, and photovoltaic cells, nine portions (defined by cell size) of each photovoltaic panel model were placed in the muffler oven (Linn

TABLE 2: Main characteristics of the photovoltaic panels used in the research.

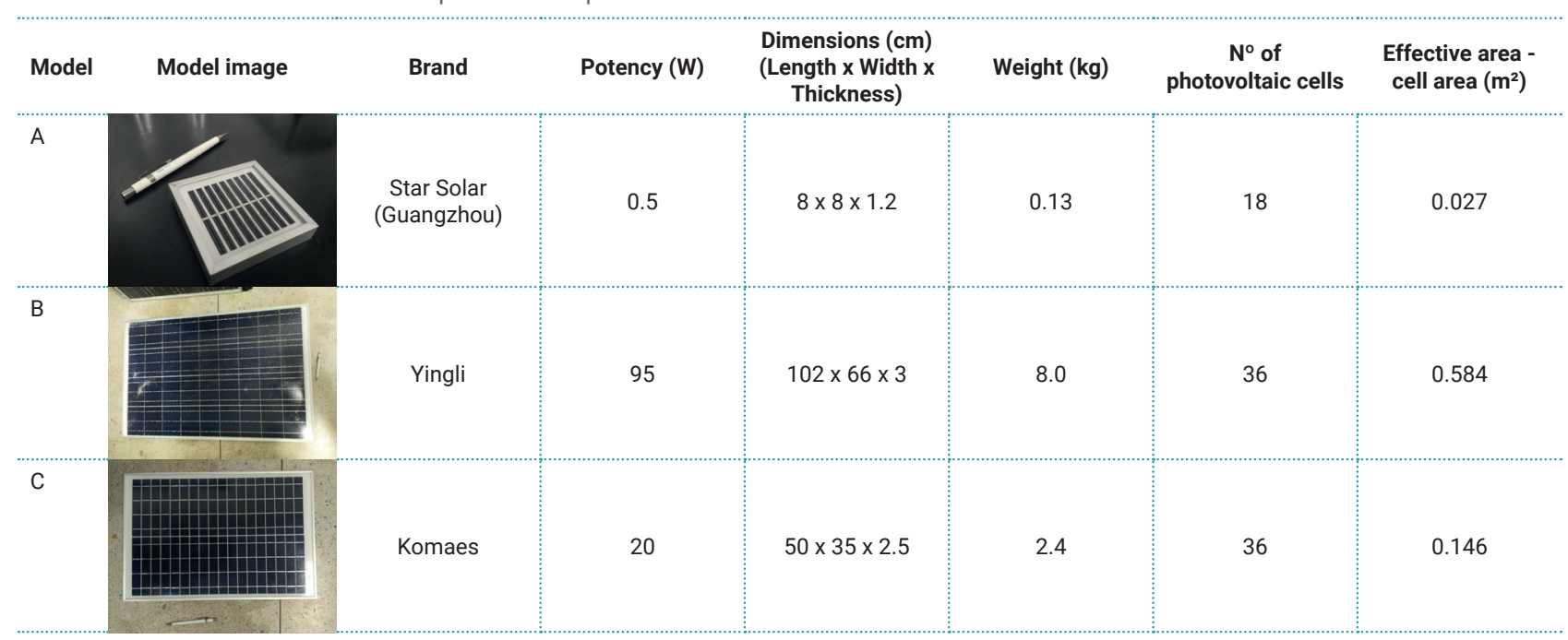



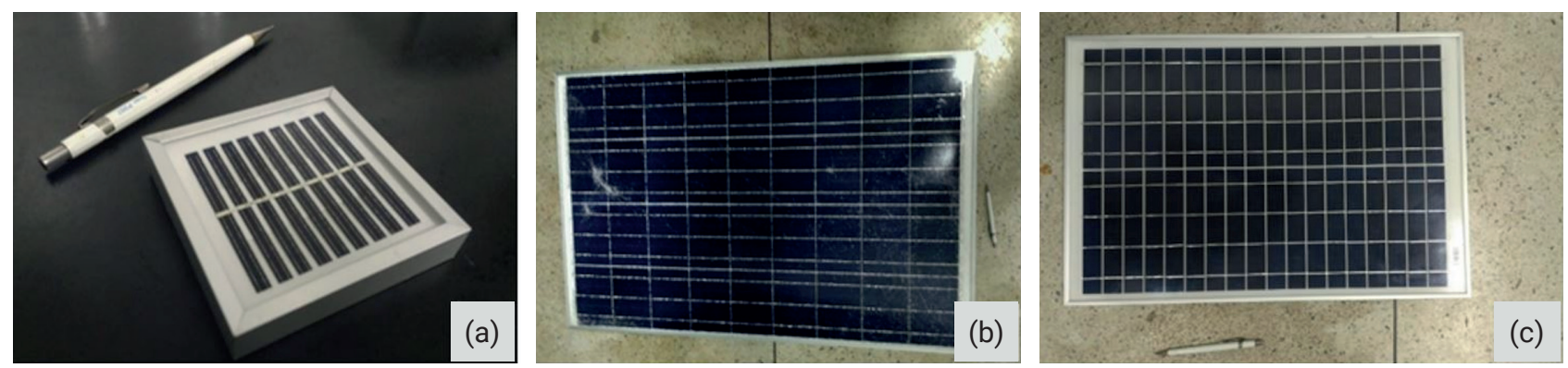

FIGURE 2: Models of photovoltaic panels used for research. Legend: (a) Star solar, (b) Yingli, and (c) Komaes.

Elektro Therm) for $20 \mathrm{~min}$ at a temperature of $600^{\circ} \mathrm{C}$, using a method adaptated from Dias et al. (2016) and Kang et al. (2012). The obtained material was weighed before and after the time in the muffler oven for determination of the polymer fraction. The glass, metal filaments, and photovoltaic cells were then manually separated and weighted.

\subsection{Step 2 - Characterization of photovoltaic cells}

The photovoltaic panels were fractionated manually and subjected to thermal separation for removal of the ethylene-vinyl acetate (EVA) polymer film. The samples were placed in the muffler oven at a temperature of $600^{\circ} \mathrm{C}$ for 20 min. The photovoltaic cells were then manually separated and comminuted in a porcelain mortar. This process is illustrated in Figure 3.

The photovoltaic cells of each photovoltaic panel were used in the determination of $\mathrm{Ag}, \mathrm{Cu}, \mathrm{Al}, \mathrm{Fe}$, and $\mathrm{Pb}$ in Steps 2 and 3 . The metals were chosen according to the composition of photovoltaic panels already reported in the literature (Dias et al., 2016; Kuczyńska-Łażewska et al., 2018a; Latunussa et al., 2016).

The characterization of the metals was carried out initially using aqua regia, which is commonly used for the determination of the metallic composition of e-waste (Dias et al., 2016; Hubau et al., 2019).

Nine photovoltaic cells comminuted from each photovoltaic panel model were digested in aqua regia, composing twenty-seven characterization tests in total. The nitric and hydrochloric acids used were previously distilled to ultrapurify them and minimize contamination of the samples. Also, all glassworks were cleaned and decontaminated by treatment in alkaline detergent solution ( $5 \% \mathrm{v} / \mathrm{v})$ for $24 \mathrm{~h}$, in acidic solution (15\% v/v) for $24 \mathrm{~h}$, and then rinsed with ultrapure water.

The samples were digested in triplicate using Erlenmeyer flasks with a nominal capacity of $250 \mathrm{~mL}$. The samples were maintained in the solution for $2 \mathrm{~h}$ at a ratio of 0.05 $\mathrm{g} / \mathrm{mL}$ and, then, filtered on a filter paper (Unifil) with 1-2 $\mu \mathrm{m}$ particle retention.

Before the filtration process, the weights of the filter paper, crucibles, and samples were measured on an analytical balance (Quimis/Q-500L210C). After filtration, the filter paper containing the insoluble fraction was oven dried (Logen Scientific) in a ceramic crucible for $48 \mathrm{~h}$ at $70^{\circ} \mathrm{C}$. Then, it was transferred to a desiccator for cooling in a moisture-free atmosphere and was again weighed in analytical balance.
The mass balance was then calculated. From the difference between the calculated mass of metals and the total weight of the sample, the mass of the silicon present in the photovoltaic cells can be estimated.

Aliquots of the liquid fraction obtained after filtration were sent for quantitative determination of $\mathrm{Cu}$ by the Inductively Coupled Plasma Spectrometry (ICP-MS) (Perkin Elmer/Nexlon 300D), as well as for the determination of $\mathrm{Ag}, \mathrm{Pb}, \mathrm{Fe}$, and $\mathrm{Al}$ by Flame Atomic Absorption Spectrometry (FAAS) (Analytik Jena/Zeenit 700). Both tests were perfomed in the Atomic Spectroscopy Laboratory at the Federal University of Espírito Santo in Brazil.

As silver can react with the hydrochloric acid present in aqua regia to form a precipitate (AgCl) (Dias et al., 2016; Yang et al., 2017), a complementary silver solubilization test was performed using the nitric acid. The results obtained in this test were used as a reference for the silver extraction in the following stages. The experiment was performed using only photovoltaic cell samples from the photovoltaic panel model that presented a higher concentration of silver during the characterization process with aqua regia.

The results obtained by leaching with nitric acid, used as a reference for the concentration of silver in the photovoltaic cells, was performed under a temperature of $55^{\circ} \mathrm{C}$ and concentration of $2.3 \mathrm{~mol} / \mathrm{L}$ of $\mathrm{HNO}_{3}$. These conditions were established after different tests to optimize the solubilization of silver.

\subsection{Step 3 - Nitric acid leaching of photovoltaic cells}

In Step 3, the comminuted photovoltaic cells, which were mechanically processed in Step 2 and stored, were used. These samples were homogenized and quartered for each model of photovoltaic cells, obtaining samples of $5 \mathrm{~g}$ each. Silver acid leaching was then carried out using nitric acid at different concentrations and controlled temperatures.

The solid-liquid ratio used was $0.05 \mathrm{~g} / \mathrm{mL}$, and in order to minimize energy costs, no magnetic stirring was used. In acid leaching, nitric acid was used at different concentrations (1-10 mol/L), simulating a range of room temperature $\left(25^{\circ} \mathrm{C}\right)$ to higher temperatures $\left(60^{\circ} \mathrm{C}\right)$. The optimal temperature $\left(42^{\circ} \mathrm{C}\right)$ for the solubilization of silver, suggested by Rojas \& Martins (2010) and by Dias et al. (2016), was also tested.

Erlenmeyer flasks with nominal capacity of $250 \mathrm{~mL}$ were placed on a shaker with heating control (Tecnal/TE0853). All procedures were performed inside a laboratory 

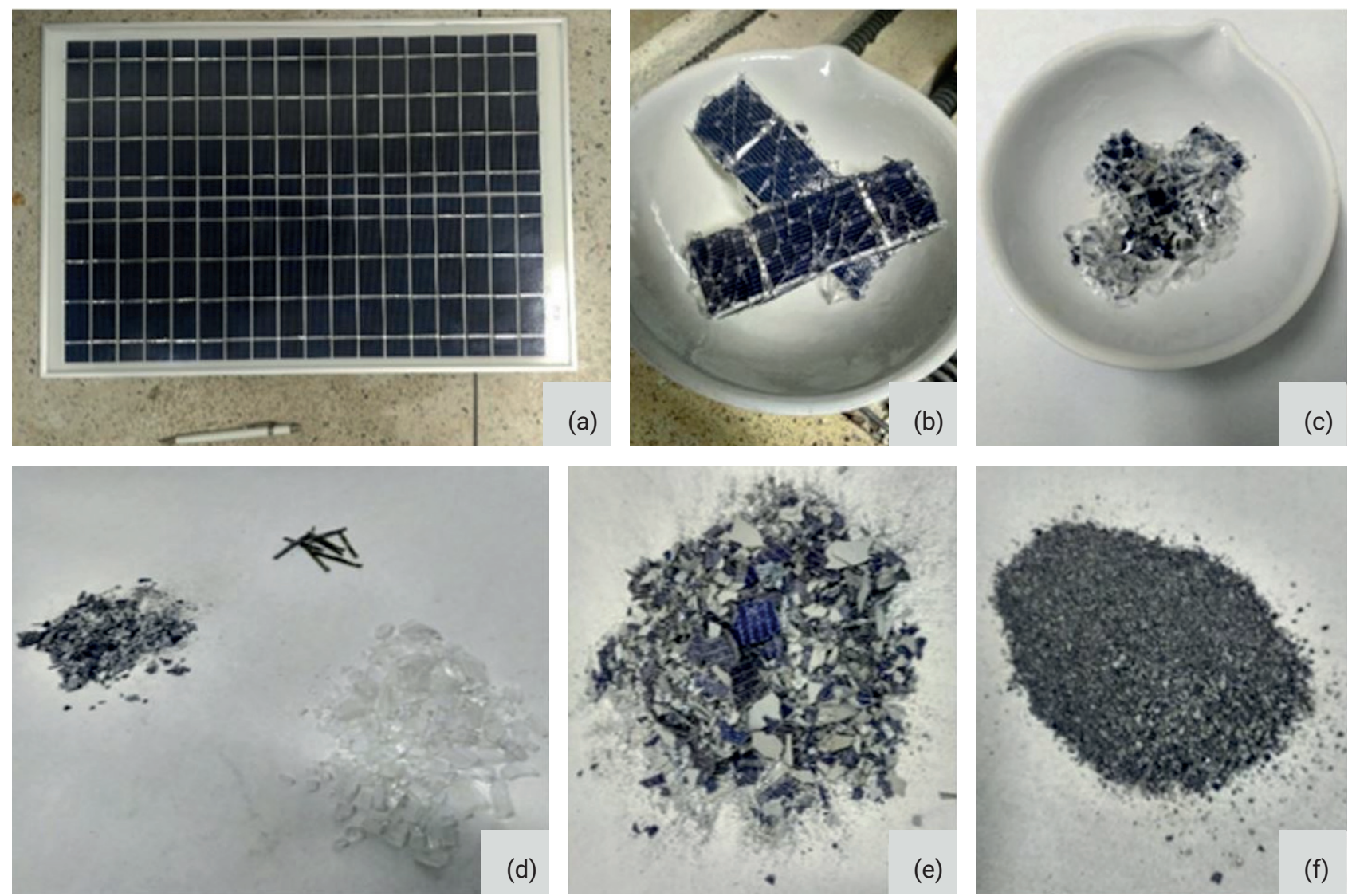

FIGURE 3: Process of separation and comminution of photovoltaic cells. Legend: a) Photovoltaic panel; b) Separated photovoltaic samples; c) Photovoltaic samples after the muffler oven; d) Manual separation of glass, metal filaments, and photovoltaic cells; e) Separated photovoltaic cells; f) Comminuted photovoltaic cells.

fume hood with forced ventilation, and the temperature of the acid leaching system was monitored using a mercury thermometer (Incoterm, $-10 /+110^{\circ} \mathrm{C}$ ).

The analytical balance was used to weigh samples of comminuted material. After 2 hours, each of the leached solutions obtained was filtered using filter paper with particle retention of 1-2 $\mu \mathrm{m}$ and were analyzed by FAAS to determine $\mathrm{Ag}, \mathrm{Pb}$, and $\mathrm{Al}$ concentrations.

Considering that results from Joda \& Rashchi (2012) and Motta (2018) showed that the Central Composite Rotational Design (CCRD) can be used to optimize the amount of tests and leaching inputs and also reach results similar to those obtained by the complete factorial method, the CCRD was used for the experimental design of the acid leaching stage.

The number of experiments was determined by the CCRD using two factors: nitric acid concentration and tem-

TABLE 3: Maximum parameters adopted and corresponding alpha values.

\begin{tabular}{l|cccccccc} 
& & \multicolumn{6}{c}{ Alpha values (a) } \\
\cline { 3 - 8 } Parameters & Codes & $\mathbf{- 1 . 4 1}$ & $\mathbf{- 1}$ & $\mathbf{0}$ & $\mathbf{1}$ & $\mathbf{1 . 4 1}$ \\
\hline $\begin{array}{l}\mathrm{HNO}_{3} \text { concentration } \\
(\mathrm{mol} / \mathrm{L})\end{array}$ & $\mathrm{X} 1$ & 1 & 2.3 & 5.5 & 8.7 & 10 \\
\hdashline \begin{tabular}{l} 
Temperature $\left({ }^{\circ} \mathrm{C}\right)$ \\
\hline
\end{tabular} & $\mathrm{X} 2$ & 25 & 30 & 42 & 55 & 60 \\
\hline
\end{tabular}

perature. Table 3 presents the alpha values generated by the model between the maximum values $\left(10 \mathrm{~mol} / \mathrm{L} ; 60^{\circ} \mathrm{C}\right)$ and minimum values $\left(1 \mathrm{~mol} / \mathrm{L} ; 25^{\circ} \mathrm{C}\right)$.

Applying the CCRD, 4 vertex points, 4 axial points, and 3 replicates were used for the center, totaling 11 experiments per model of photovoltaic panel, as shown in Table 4.

From the experimental results, a mathematical model was determined, and response surfaces were generated.

TABLE 4: Tests stipulated by the CCRD.

\begin{tabular}{c|c|c} 
Experiment $\left(\mathbf{n}^{\circ}\right)$ & $\begin{array}{c}\text { HNO }_{3} \text { concentration } \\
(\mathbf{m o l} / \mathbf{L})\end{array}$ & Temperature $\left({ }^{\circ} \mathbf{C}\right)$ \\
\hline 1 & 2.3 & 30 \\
\hline 2 & 8.7 & 30 \\
\hline 3 & 2.3 & 55 \\
\hline 4 & 8.7 & 55 \\
\hline 5 & 1 & 42 \\
\hline 6 & 10 & 42 \\
\hline 7 & 5.5 & 25 \\
\hline 8 & 5.5 & 60 \\
\hline 9 & 5.5 & 42 \\
\hline 10 & 5.5 & 42 \\
\hline 11 & 5.5 & 42 \\
\hline
\end{tabular}


Using a statistical tool of analysis of variance (ANOVA), the significance and adequacy of the model was tested. For analysis of the data, the Fischer variation ratio (F value) was also applied, providing a statistically valid measure of how well the factors describe the variation in the mean data.

\subsection{Step 4 - Analysis of nitric acid leaching of silver versus time}

The combination of temperature and nitric acid concentration, identified in Step 3 as more efficient for acid leaching of silver, was adopted in a new experiment. In this experiment, three quartered samples of $5 \mathrm{~g}$ of the photovoltaic panel model $\mathrm{C}$ were used. To optimize the testing time, $10 \mathrm{~mL}$ aliquots were sampled every 30 min for analysis in order to construct the silver extraction ratio curve with respect to the reaction time. With the results of the triplicates, the extraction averages were calculated for each time period.

The aliquots were filtered and used for analysis by FAAS to determine the $\mathrm{Ag}, \mathrm{Pb}$, and $\mathrm{Al}$ concentration. The leached solutions were separated so that the one with the highest solubilization of silver was used in Step 5.

\subsection{Step 5 - Silver recovery by precipitation}

This step aimed to determine the silver recovery by chemical and electrochemical precipitation while comparing the obtained results.

\subsubsection{Chemical precipitation of silver}

In the chemical precipitation, the sodium carbonate and hydrochloric acid reagents were used, which were selected based on the information from Vogel (1981) regarding their effectiveness on silver precipitation.

After the acid leaching, about $200 \mathrm{~mL}$ of the solution obtained in the optimum silver extraction conditions were separated for the precipitation step.

A solution of $0.1 \mathrm{~mol} / \mathrm{L}$ sodium carbonate $\left(\mathrm{Na}_{2} \mathrm{CO}_{3}\right)$ was added to $50 \mathrm{~mL}$ of the sample to precipitate silver carbonate $\left(\mathrm{Ag}_{2} \mathrm{CO}_{3}\right)$, according to the reaction presented in Equation 1:

$\mathrm{Na}_{2} \mathrm{CO}_{3}+2 \mathrm{AgNO}_{3} \leftrightarrow \mathrm{Ag}_{2} \mathrm{CO}_{3} \downarrow+2 \mathrm{NaNO}_{3}$

The amount of sodium carbonate solution added was calculated by stoichiometry, augmenting with an additional $20 \%(\mathrm{v} / \mathrm{v})$ from the calculated value. This was based on the silver concentration determined by FAAS.

In another $50 \mathrm{~mL}$ of the sample, a $37 \%$ hydrochloric acid solution $(\mathrm{HCl})$ was added to precipitate the silver chloride $(\mathrm{AgCl})$, according to the reaction presented in Equation 2:

$\mathrm{HCl}+\mathrm{AgNO}_{3} \leftrightarrow \mathrm{AgCl} \downarrow+\mathrm{HNO}_{3}$

The amount of hydrochloric acid solution added was also calculated by stoichiometry, augmenting with an additional $20 \%$ (v/v) from the calculated value. This was based on the silver concentration determined by FAAS. The solutions were filtered by quantitative filter paper with 1-2 $\mu \mathrm{m}$ particle retention, and an aliquot of the solution was removed for ICP-MS analysis to determine the residual silver concentration of each experiment.

\subsubsection{Electrochemical silver precipitation}

In this test, $50 \mathrm{~mL}$ of the leached solutions were submitted to an electrochemical process for the precipitation of silver in solution.

A platinum plate $(7 \mathrm{~cm} \times 2 \mathrm{~cm})$ was used as a positive electrode, a steel plate $(7 \mathrm{~cm} \times 2 \mathrm{~cm})$ was used as a negative electrode, and the current density was $60 \mathrm{~A} / \mathrm{m}^{2}$. Based on the analyses performed by Lee et al. (2013) and Raju, Chung, \& Moon (2009), the test was maintained for $1 \mathrm{~h}$. The space between the electrodes was $30 \mathrm{~mm}$, and the temperature was $21^{\circ} \mathrm{C}$. The $\mathrm{pH}$ of the solution at the time of the experiment was 2.5. To perform the experiment, the electrolytic cell was mounted in a $100 \mathrm{~mL}$ glass vessel with the platinum electrode and the stainless-steel electrode used as anode and cathode, respectively.

The electrodes were connected to a digital electric source (Minipa/MPS-3005, 30V/5A) to provide direct current, and the voltage and current were monitored using a multimeter (Minipa/MA-149). The leached solution was then filtered via quantitative filter paper with particle retention of 1-2 $\mu \mathrm{m}$, and the liquid fraction was analyzed by FAAS to determine the residual silver concentration.

\section{RESULTS AND DISCUSSION}

Following the five steps described in section 2, it was possible to achieve and discuss some results that are presented in sections 3.1 to 3.5. The experimental planning and its results were analyzed with the support of statistical tools and professionals in order to ensure its reability.

\subsection{Step 1 - Gravimetric composition of end-of-life photovoltaic panels}

Table 5 shows the average composition of each analyzed material for the three photovoltaic panel models, presenting the standard deviation and the mean. The composition of each panel is also shown in Figure 4.

Latunussa et al. (2016) observed that the photovoltaic panel consisted of $70 \%$ glass, $18 \%$ aluminum frame, $5.1 \%$ EVA (polymer), 3.7\% photovoltaic cell, and $1.5 \%$ backsheet polymer, among other materials.

These data corroborate the result obtained in this stage of the research, showing differences regarding the percentage of glass and aluminum for Model $A$. The photovoltaic panel of Model A was made with a glass of lower resistance; however, it had a reinforced aluminum frame, justi-

TABLE 5: Statistical analysis of the gravimetric composition of the photovoltaic panel models (percentage by mass).

\begin{tabular}{c|c|c|c|c|c}
$\begin{array}{c}\text { Variable } \\
(\%)\end{array}$ & $\begin{array}{c}\text { Aluminum } \\
\text { Frame }\end{array}$ & Glass & Cell & Filaments & Polymers \\
\hline Panel A & 49.98 & 36.73 & 1.91 & 0.35 & 11.04 \\
\hline Panel B & 12.68 & 70.9 & 4.89 & 0.65 & 10.88 \\
\hline Panel C & 14.86 & 68.16 & 4.01 & 0.87 & 12.10 \\
\hline Mean & 25.84 & 58.60 & 3.60 & 0.62 & 11.34 \\
\hline $\begin{array}{l}\text { Standard } \\
\text { deviation }\end{array}$ & 20.93 & 18.99 & 1.53 & 0.26 & 0.67 \\
\hline
\end{tabular}




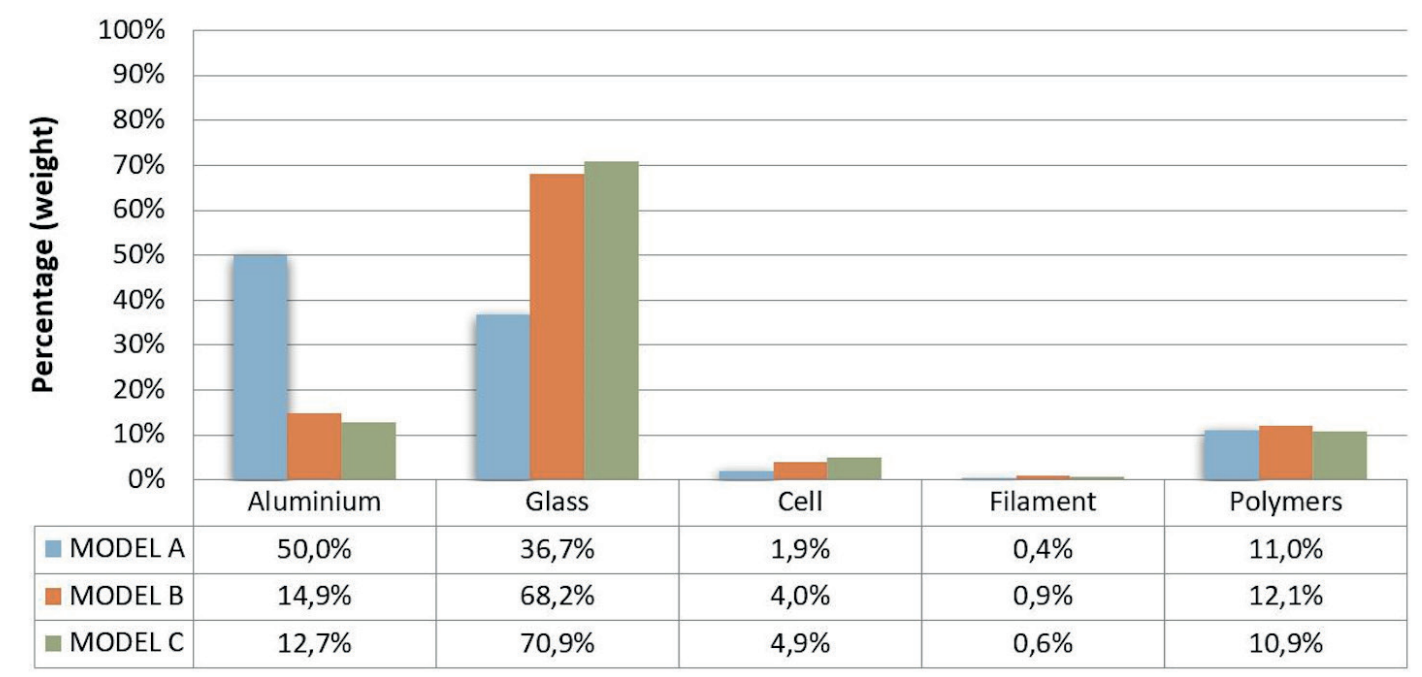

FIGURE 4: Gravimetric composition of analyzed photovoltaic panels (percentage by mass).

fying the obtained result. The other observed differences resulted from variation in the model and manufacturer of photovoltaic panels.

The fraction where the silver is found (photovoltaic cell) is superior in the composition of photovoltaic panels when compared to the percentage of PCB from e-waste, which is widely studied for the recovery of metals (Hubau et al., 2019; Motta, 2018; Rebelllo, 2018). Photovoltaic panels also have less heterogeneity than other e-wastes. For example, the composition of the photovoltaic panels is more than $80 \%$ glass and aluminum frame, which are materials that can be separated and recycled. Thus, determination of the gravimetric composition of the photovoltaic panels indicates the relevance of studies aimed at the recycling these materials.

\subsection{Step 2 - Characterization of photovoltaic cells}

Table 6 summarizes the characterization results for the photovoltaic cells of the three models and shows the average concentration of each metal, the metals not identified in this study, and the fraction of silicon of the cells.

According to Paiano (2015), other metals such as zinc and tin can also be part of photovoltaic cells, possibly be- ing components of the metals fraction not identified in the present work.

For Model A, the silver presented a concentration of $0.29 \mathrm{~kg} /$ ton in photovoltaic cells. Model B presented about $0.86 \mathrm{~kg}$ of silver per ton in photovoltaic cells. Approximately $2.6 \mathrm{~kg}$ of silver per ton of photovoltaic cells were found in Model C.

From the results obtained in the characterization with aqua regia, Model $\mathrm{C}$ of the photovoltaic panels was selected for use in a leaching test with nitric acid because it presented a higher concentration of silver. Figure 5 shows the composition of photovoltaic panel $\mathrm{C}$, considering the new silver concentration result obtained through nitric acid leaching.

Using this reference value for silver, it is inferred that it is possible to recover up to $6.87 \mathrm{~kg}$ of silver in one ton of photovoltaic cells. This result is close to the one found by Chen et al. (2020), reporting $5.7 \mathrm{~kg}$ of silver in one ton of photovoltaic cells. Based on these results and aiming at the recycling of silver, the characterization with nitric acid should be preferentially used, since it allows for greater solubilization of this metal in relation to the digestion with aqua regia.

TABLE 6: Characterization of the photovoltaic cells of the different models of photovoltaic panels.

\begin{tabular}{|c|c|c|c|c|c|c|c|}
\hline \multirow{2}{*}{ Variable (\%) } & \multicolumn{7}{|c|}{ Composition of the photovoltaic cell (\% by mass) } \\
\hline & Silver (Ag) & Copper (Cu) & Aluminium (Al) & Lead $(\mathrm{Pb})$ & Iron (Fe) & Other metals & Silicon (Si) \\
\hline Model A & 0.03 & 1.20 & 3.30 & 0.13 & $<\mathrm{DL}$ & 3.78 & 91.55 \\
\hline$\sigma \mathrm{A}$ & 0.01 & 0.69 & 0.84 & 0.10 & - & 9.71 & 3.04 \\
\hline Model B & 0.09 & 0.02 & 6.73 & 0.27 & 0.005 & 2.18 & 90.71 \\
\hline$\sigma \mathrm{B}$ & 0.01 & 0.02 & 0.83 & 0.18 & 0.001 & 10.87 & 1.64 \\
\hline Model C & 0.26 & 0.01 & 5.77 & 0.06 & 0.006 & 0.96 & 92.93 \\
\hline$\sigma C$ & 0.07 & 0.01 & 0.63 & 0.02 & 0.005 & 6.81 & 0.43 \\
\hline Mean & 0.13 & 0.41 & 5.27 & 0.15 & 0.004 & 2.31 & 91.73 \\
\hline$\sigma$ & 0.12 & 0.69 & 1.77 & 0.11 & 0.003 & 1.41 & 1.12 \\
\hline
\end{tabular}

Legend: $\sigma=$ Standard deviation; $D L=$ detection limit ( $L Q f e r r o=0.316 \mathrm{mg} / \mathrm{L}$ ) 


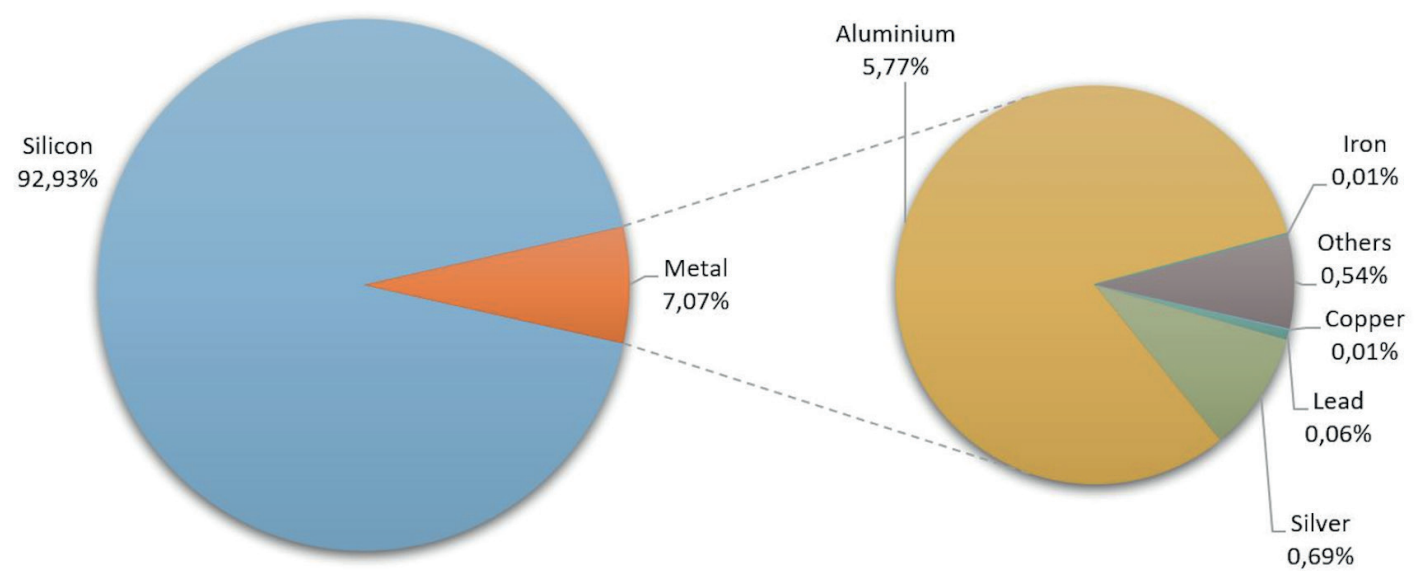

FIGURE 5: Characterization of the photovoltaic cells from Photovoltaic Panel Model C, considering the silver concentration obtained in the solubilization with nitric acid.

Padoan et al. (2019) provided a review on the recycling of photovoltaic panels and showed that literature presents an Ag concentration in photovoltaic panels that ranges between $60-525 \mathrm{mg} / \mathrm{kg}$. The present research observed 336 $\mathrm{mg} / \mathrm{kg}$, which is a result that is close to the average proposed by Padoan et al (about $300 \mathrm{mg} / \mathrm{kg}$ ).

Regarding silver, it is possible to observe that the concentration range in photovoltaic cells reported in the different studies (0.08-1.67\%) is higher than that found in PCB (0.06-0.21\%) (Kasper et al., 2011; Lee et al., 2013; Olson et al., 2013). According to the U.S. Geological Survey (2015), economically viable extraction of silver from ore requires a minimum concentration of $0.07 \%$ by mass. Thus, the importance of silver recovery from photovoltaic cells is justified, according to the experiments performed in the present study because its concentration in photovoltaic cells is up to $0.69 \%$.

\subsection{Step 3 - Nitric acid leaching of photovoltaic cells}

In the nitric acid leaching stage, only Model $\mathrm{C}$ of the photovoltaic panels was studied, since it presented a high- er concentration of silver, according to Step 2. Each experiment at this stage was performed for 2 hours. The results obtained for the silver acid leaching experiments of the photovoltaic cells, as well as the parameters used, are presented in Table 7.

Table 7 also shows the results for solubilized aluminum and lead concentrations, and these elements were determined together with silver because they presented higher concentrations than the other metals in the characterization step.

From the statistical analysis using ANOVA, the values of the statistically significant coefficients were generated. From these, it was possible to create a mathematical model (Equation 3), which indicates the percentage of silver extraction as a function of temperature and acid concentration.

Silver solubilization $(\%)=$

$$
=-0.39 \times\left[\mathrm{HNO}_{-} 3\right]^{2}-0.015 \times[\mathrm{T}]^{2}+5.24 \times\left[\mathrm{HNO}_{3}\right]+1.77 \times \mathrm{T}
$$

The mathematical model for the CCRD presented an $\mathrm{R}^{2}=0.99$. In this sense, based on the $\mathrm{R}^{2}$ value, the CCRD

TABLE 7: Results of silver, lead, and aluminum concentration obtained in the acid leaching tests with $2 \mathrm{~h}$ of duration for Model $\mathrm{C}$ of photovoltaic panel.

\begin{tabular}{|c|c|c|c|c|c|c|c|c|}
\hline \multirow{2}{*}{$\begin{array}{l}\text { Experiment } \\
\left(n^{\circ}\right)\end{array}$} & \multirow{2}{*}{$\begin{array}{c}\text { Concentration } \\
\text { of } \mathrm{HNO}_{3} \\
(\mathrm{~mol} / \mathrm{L})\end{array}$} & \multirow{2}{*}{$\begin{array}{c}\text { Temperature } \\
\left({ }^{\circ} \mathrm{C}\right)\end{array}$} & \multicolumn{2}{|c|}{$\mathbf{A g}$} & \multicolumn{2}{|c|}{ Al } & \multicolumn{2}{|c|}{$\mathrm{Pb}$} \\
\hline & & & $\mathrm{mg} / \mathrm{L}$ & $\%$ & $\mathrm{mg} / \mathrm{L}$ & $\%$ & $\mathrm{mg} / \mathrm{L}$ & $\%$ \\
\hline 1 & 2.3 & 30 & 171.08 & 50 & 2492.75 & 74 & 42.25 & 30 \\
\hline 2 & 8.7 & 30 & 203.25 & 59 & 2525.00 & 75 & 3.22 & 2 \\
\hline 3 & 2.3 & 55 & 254.18 & 74 & 3490.00 & 100 & 55.00 & 39 \\
\hline 4 & 8.7 & 55 & 234.73 & 68 & 2845.00 & 85 & 42.03 & 30 \\
\hline 5 & 1 & 42 & $<\mathrm{DL}$ & $<D L$ & 1686.75 & 50 & 16.70 & 12 \\
\hline 6 & 10 & 42 & 207.85 & 60 & 2665.00 & 80 & 72.38 & 52 \\
\hline 7 & 5.5 & 25 & 180.13 & 52 & 2252.75 & 67 & 46.43 & 33 \\
\hline 8 & 5.5 & 60 & 218.53 & 63 & 3352.50 & 100 & 47.00 & 34 \\
\hline 9 & 5.5 & 42 & 243.20 & 71 & 2637.50 & 79 & 52.30 & 37 \\
\hline 10 & 5.5 & 42 & 208.83 & 61 & 3095.00 & 92 & 41.98 & 30 \\
\hline 11 & 5.5 & 42 & 216.60 & 63 & 2757.50 & 82 & 84.08 & 60 \\
\hline
\end{tabular}

Legend: $D L=$ Detection limit $(D L A g=0.07754)$ 


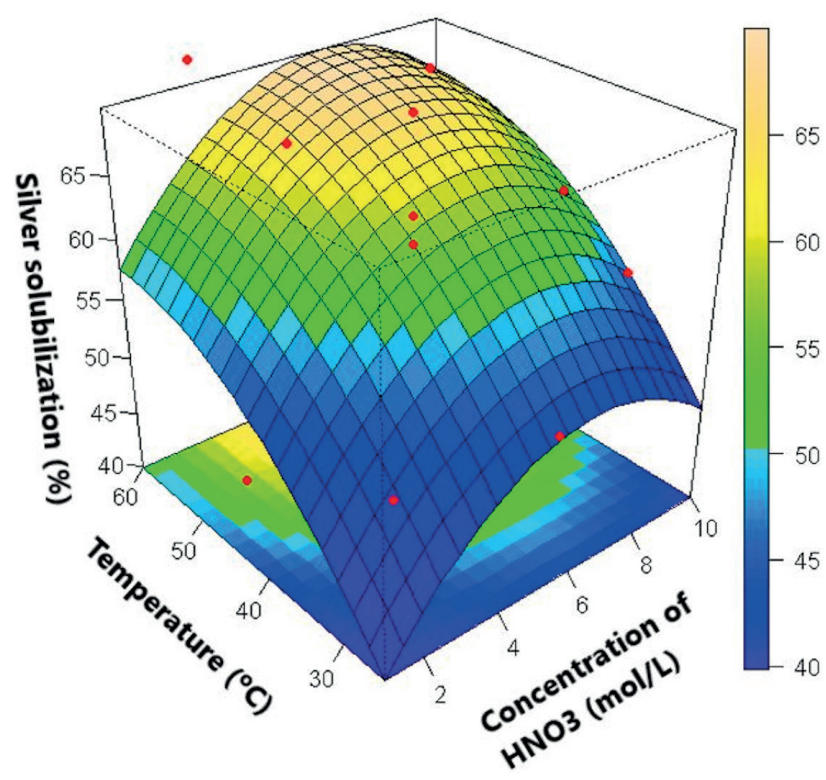

FIGURE 6: Contour curve for the central composite rotational design model - Model C.

model can be used as a predictive model (Joda \& Rashchi, 2012). Figure 6 shows the contour curve generated from the mathematical model obtained with the significant parameters and using the software Action.

The yellow-orange color area in the graph shown in Figure 6 shows the combination of temperature and nitric acid concentration, obtaining better silver solubilization (60-70\%). The response surface generated from the results suggests, among the ranges of parameters analyzed, that temperatures between $50-60^{\circ} \mathrm{C}$ combined with $\mathrm{HNO}_{3}$ concentration between $2-10 \mathrm{~mol} / \mathrm{L}$ are better applicable for the solubilization of silver present in photovoltaic cells. Using the Minitab software, the main effects graph was generated, as shown in Figure 7.

As observed in Figure 7, there is no great variation in the silver solubilization percentage (60-63\%) in the nitrate acid concentration range of $2.3-10 \mathrm{~mol} / \mathrm{L}$, and therefore, it was de- cided to adopt $55^{\circ} \mathrm{C}$ and an $\mathrm{HNO}_{3}$ concentration of $2.3 \mathrm{~mol} / \mathrm{L}$ as optimum parameters, considering that this test allowed for the solubilization of $74 \%$ of the silver. These parameters were further defined in order to minimize the use of nitric acid, since a lower concentration of the reagent is used.

In their study, Joda \& Rashchi (2012) used a CCRD and performed acid leaching, obtaining up to $87.3 \%$ of silver solubilization with temperatures between $60-70^{\circ} \mathrm{C}$ and $\mathrm{HNO}_{3}$ concentrations between 3-4 mol/L. They also observed the increase in PCB silver extraction by increasing the $\mathrm{HNO}_{3}$ concentration.

These parameters are also close to those calculated in the current research as optimal for silver extraction. It is well known that silver extraction can be obtained with nitric acid leaching (Deng et al., 2019; Tao \& Yu, 2015; Yousef et al., 2019); however, parameters such as temperature, acid concentration, reaction time, and solid ratio still need to be explored, as many different results are obtained with the variation of this parameters (Dias et al., 2016; Shin et al., 2017; Yousef et al., 2019).

\subsection{Step 4 - Analysis of nitric acid leaching of silver versus time}

At this stage, the optimum conditions of temperature $\left(55^{\circ} \mathrm{C}\right)$ and nitric acid concentration $(2.3 \mathrm{~mol} / \mathrm{L})$, identified by the response surface method (Fig.6) and by the main effects graph for acid leaching of silver (Fig.7), were used in a new experiment. The aim was to analyze the reaction time of $2 \mathrm{~h}$, based on the results of Dias et al. (2016), Joda \& Rashchi (2012), and Lee et al. (2013). Figure 8 shows the percentages of extraction of $\mathrm{Ag}, \mathrm{Al}$, and $\mathrm{Pb}$ over time.

The values of silver extraction by time, presented in Figure 8 , were calculated based on the relationship between the concentration of silver obtained in the reference leaching (nitric acid) and the results obtained by time in the present step. The solubilization of the other metals ( $\mathrm{Pb}$ and $\mathrm{Al}$ ) was compared with the average obtained in the characterization with aqua regia.

Rojas \& Martins (2010) studied the recovery of Ag of jewelry scraps using concentrated nitric acid and conclud-

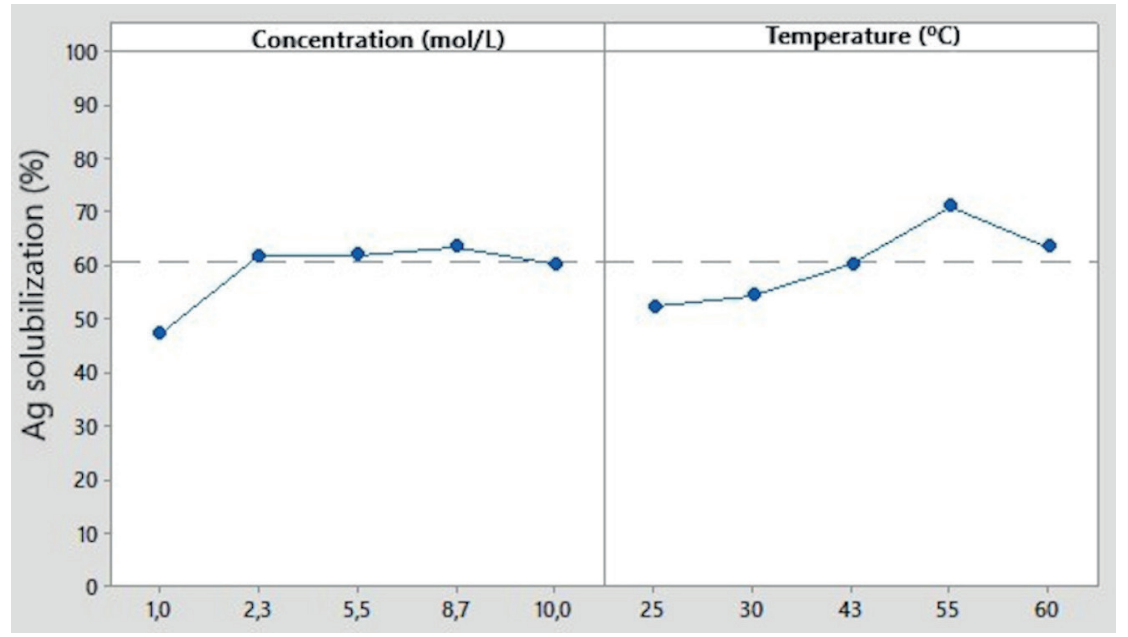

FIGURE 7: Main Effects for Ag Solubilization (\%). 


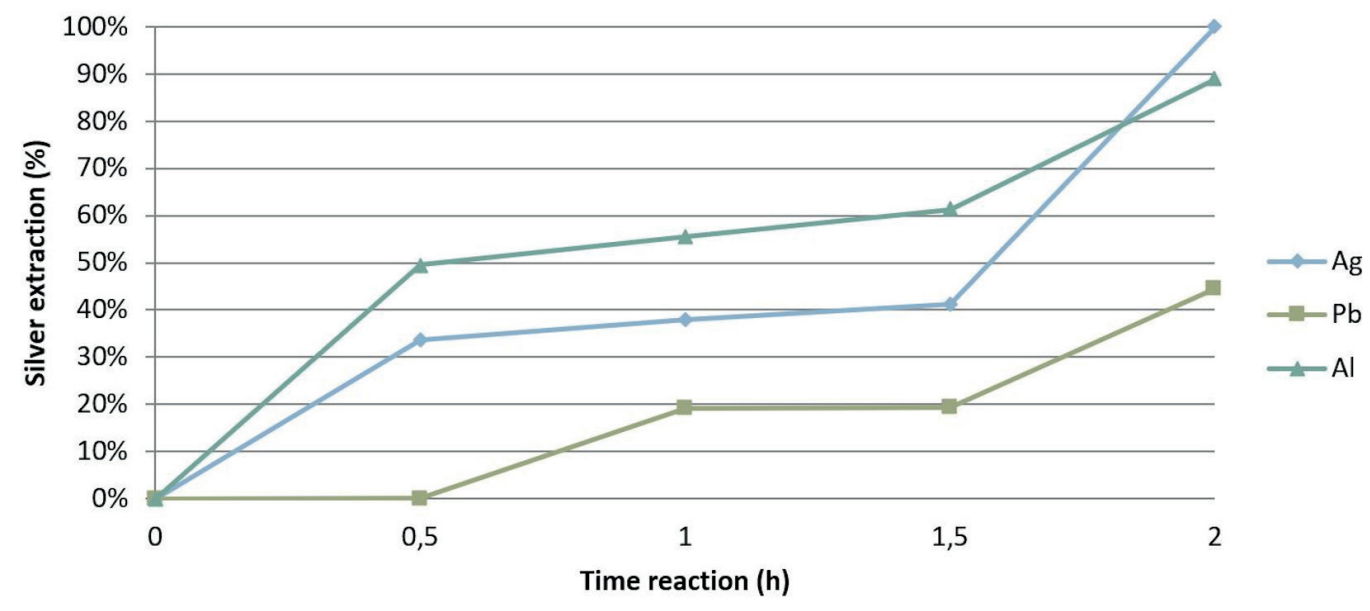

FIGURE 8: Percentage of $\mathrm{Ag}, \mathrm{Pb}$, and $\mathrm{Al}$ extraction versus time - Model C.

ed that about 2 hours at a temperature of $43^{\circ} \mathrm{C}$ was an ideal reaction time. These results corroborate those found in the present study, where the reaction time of $2 \mathrm{~h}$ with a temperature of $55^{\circ} \mathrm{C}$ was able to solubilize $95 \%$ of the silver present in the photovoltaic cell. Although the temperature used is $12^{\circ} \mathrm{C}$ higher than that used in the Rojas \& Martins research, dilute nitric acid $(2.3 \mathrm{~mol} / \mathrm{L})$ was used here.

Chen et al. (2020) used a $4 \mathrm{~mol} / \mathrm{L}$ nitric acid concentration under the conditions of $80^{\circ} \mathrm{C}$ for 4 hours, and then, $3 \mathrm{~mol} / \mathrm{L}$ sodium hydroxide at $70^{\circ} \mathrm{C}$ for 3 hours achieved a leaching efficiency of $99.7 \%$ of $\mathrm{Ag}$ and $99.9 \%$ of $\mathrm{Al}$ from photovoltaic solar panels. In the present study, Ag solubilization was achieved with less time reaction, a less concentrated acid, and a lower temperature. However, the Al leaching was lower than that achieved by Chen et al. (2020), who peformed an extra leaching experiment with sodium hydroxide. Savvilotidou \& Gidarakos (2019) also analized the extraction and concentration of silver from waste crystalline silicon photovoltaic panels. The leaching conditions used were a solid:liquid ratio of $0.02,30 \% \mathrm{HNO}_{3}$, controlled temperature of $20^{\circ} \mathrm{C}$, constant agitation of $150 \mathrm{rpm}$ for one hour experiment, and they achieved $93-100 \%$ of $\mathrm{Ag}$ leaching efficiency. Comparing with this experiment, both the results and the applied parameters are very similar. The temperature used by Savvilotidou \& Gidarakos (2019) was lower, but a higher acid concentration was applied. Though their reaction time was lower, they used a magnectic stirrer, which was not used in the present study.

In order to apply Equation 3 from Step 3, the parameters used in other researches were added to the equation to estimate the silver leaching results (Table 8). As the optimum result was obtained at Step 4 when the best conditions from Step 3 were applied to a new experiment, the equation results were the compared.

Some of the equation results underestimate the real silver leaching percentage obtained by the authors. This can be explained by the variation of other parameters (reaction time, solid liquid ratio, and agitation) that are not apply in the equation.

Considering that photovoltaic cells are mainly composed of $\mathrm{Al}, \mathrm{Ag}$, and $\mathrm{Si}$, the remaining comminuted and filtered material after the acid leaching process will be mostly silicon, which can also be recovered (Lee et al., 2013; Padoan et al., 2019).

For silver reuse, it is important that its extraction occurs selectively, providing a metal of greater purity. However, about $88 \%$ of aluminum and $44 \%$ of lead was also solubilized. Thus, it is necessary to use other processes to separate these metals. Solubilization of $\mathrm{Al}$ and $\mathrm{Pb}$ indicates that nitric acid leaching can also be used to recover these metals that have additional economic value. Otherwise, the other metals like lead need to be removed to avoid contamination, as it is considered a potentially toxic metal.

\subsection{Step 5 - Silver recovery by precipitation}

In this step, the silver extraction was determined by chemical and electrochemical precipitation to compare these results. In order to perform this test, the leaching solution obtained in Step 4 was used with the following pa-

TABLE 8: Comparison between Silver leaching results estimated by Equation 3 and other researches that apllied nitric acid leaching.

\begin{tabular}{|c|c|c|c|c|c|}
\hline Reference & $\begin{array}{c}\mathrm{HNO}_{3} \text { concentration } \\
(\mathrm{mol} / \mathrm{L})\end{array}$ & Temperature $\left({ }^{\circ} \mathrm{C}\right)$ & Other parameters & $\begin{array}{l}\text { Silver leaching results } \\
(\%)\end{array}$ & $\begin{array}{l}\text { Silver leaching esti- } \\
\text { mate by Equation } 3(\%)\end{array}$ \\
\hline Present article & 2.3 & 55 & $0.05 \mathrm{~g} / \mathrm{mL}, 2 \mathrm{~h}$ & 100 & 100 \\
\hline C.-H. Lee et al. (2018) & 5 & 70 & $0.1 \mathrm{~g} / \mathrm{mL}, 2 \mathrm{~h}$ & Not analized & 100 \\
\hline Chen et al. (2020) & 4 & 80 & $0.01 \mathrm{~g} / \mathrm{mL}, 4 \mathrm{~h}$ & 99.7 & 97 \\
\hline $\begin{array}{l}\text { Savvilotidou \& Gidara- } \\
\text { kos, (2019) }\end{array}$ & 6.45 & 20 & $\begin{array}{c}0.02 \mathrm{~g} / \mathrm{mL}, 1 \mathrm{~h} \text {, mag- } \\
\text { netic agitation }\end{array}$ & 93 & 76 \\
\hline (Dias et al. (2016) & 13.8 & 25 & $\begin{array}{c}0.05 \mathrm{~g} / \mathrm{mL}, 2 \mathrm{~h}, \text { mag- } \\
\text { netic agitation }\end{array}$ & 94 & 53 \\
\hline
\end{tabular}


rameters: temperature of $55^{\circ} \mathrm{C}$, concentration of $\mathrm{HNO}_{3}$ of $2.3 \mathrm{~mol} / \mathrm{L}$, and reaction time of 2 hours. Figure 9 shows the percentage of silver extraction obtained by each evaluated method.

The chemical precipitation with sodium carbonate extracted about $48 \%$ of the silver in solution, suggesting that this is not a suitable reagent under the circumstances analyzed in this experiment. This was also the method with the highest precipitation of the other metals in solution (32\% of $\mathrm{Pb}$ and $25 \%$ of $\mathrm{Al}$ ), causing greater contamination of the precipitate.

The methods that presented the highest silver removal efficiency were electroprecipitation and the addition of hydrochloric acid, recovering $99.98 \%$ and $99.93 \%$, respectively, of silver in solution.

Yousef et al. (2019) studied the Ag extraction from photovoltaic panels using nitric while adding $\mathrm{HCl}$ to the solution, and they achieved $97.65 \%$ of silver extraction. Lee et al. (2013) analyzed the silver precipitation by addition of $\mathrm{HCl}$ and by electroprecipitation. In its study, $\mathrm{HCl}$ was added to solution containing $\mathrm{Ag}$. The reaction was maintained for $2 \mathrm{~h}$ at different temperatures, obtaining the maximum recovery of $89.74 \%$ of $\mathrm{Ag}$. In the electrochemical analysis, the experiment was conducted for $4 \mathrm{~h}$ with 50 $\mathrm{mL}$ of the electrolytic solution with an electrical density of $60 \mathrm{~A} / \mathrm{m}^{2}$ at $\mathrm{pH} 5$, obtaining a recovery of $87.44 \%$ of the silver in solution.

In the present study, it was possible to precipitate over $99 \%$ of the silver with the addition of $\mathrm{HCl}$ and reaction time of $5 \mathrm{~min}$, which is more than what was obtained by both Lee et al. (2013) and Yousef et al. (2019). In the electrochemical assay, it was also possible to precipitate over $99 \%$ of the silver by applying a current density of $60 \mathrm{~A} / \mathrm{m}^{2}$ at a $2.5 \mathrm{pH}$ and a reaction time of $1 \mathrm{~h}$. Thus, in the present study, the results were better than those of Lee et al. (2013), although there was a shorter reaction time.
As observed, the electrochemical process and the chemical precipitation with addition of $\mathrm{HCl}$ were shown to be equivalent in relation to the silver extraction.

Chemical precipitation has higher costs for reagents. However, the development of processes allowing for the regeneration of the employed reactants could reduce the environmental impact and the processing costs of chemical methods (Padoan et al., 2019).

According to Prado \& Ruotolo (2016), although there is energy consumption in the electrochemical process, it can still be economically attractive when comparing the prices of energy and metallic silver. However, the used parameters, such as electrode potential and the applied current, require strict control during electrolysis in order to avoid uncontrolled reactions and thus loss of recoverable silver (Prado \& Ruotolo, 2016).

Electroprecipitation presents lesser contamination of lead in the precipitate, however, other factors should be analyzed to determine which is better, and there should also be more replicates of this experiment to ensure this is a phenomenon rather than some experiment error. When comparing the percentage of precipitation between the three procedures, it is observed that the electrochemical procedure and the chemical precipitation with $\mathrm{HCl}$ present very close values. This indicates that the two procedures are equivalent in terms of percentage of recovery. However, the $\mathrm{Na}_{2} \mathrm{CO}_{3}$ chemical precipitation procedure differs greatly from the others. This result can be explained by the solubility of the salts. $\mathrm{Ag}_{2} \mathrm{CO}_{3}$ is more soluble than $\mathrm{AgCl}$ under the same conditions, which results in a lower percentage of silver precipitation when carbonate is used. For lead, the situation is reversed, that is, $\mathrm{PbCl}_{2}$ is much more soluble than $\mathrm{PbCO}_{3}$, and this results in less lead precipitation when $\mathrm{HCl}$ is used as a precipitant. Electrochemically, the lead reduction potential is very low, which makes it difficult to reduce and, consequently, makes its precipitation difficult.

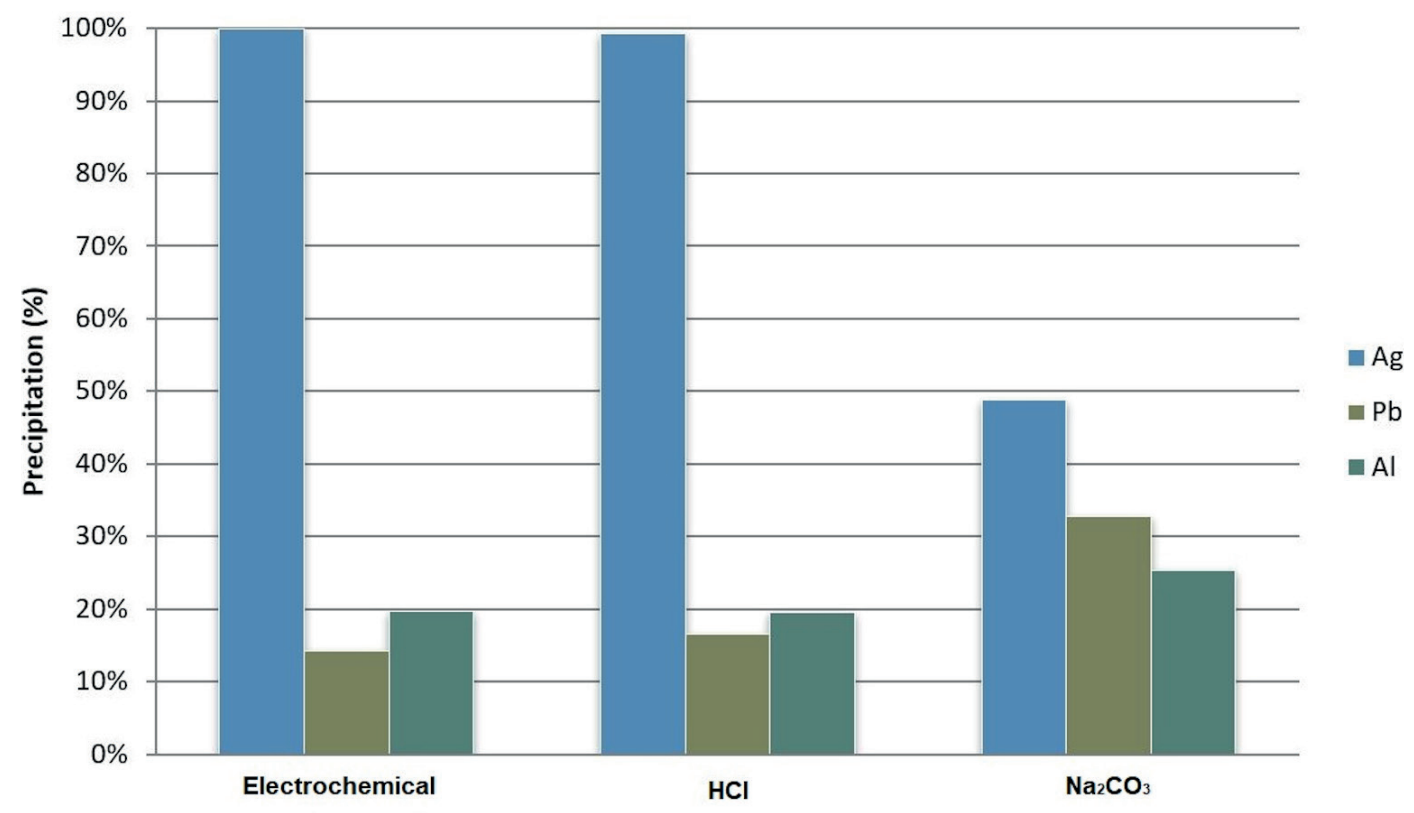

FIGURE 9: Percentage of silver, lead, and aluminum extraction of photovoltaic cells from Photovoltaic Panel Model $\mathrm{C}$ by chemical precipitation $\left(\mathrm{HCl}\right.$ and $\left.\mathrm{Na}_{2} \mathrm{CO}_{3}\right)$ and electroprecipitation. 
Though it is of great importance the research on a laboratorial scale to improve parameters of the photovoltaic panels recycling, it is also important to consider the issues to take it to the commercial scale. Zhang \& Xu (2016) emphasized the importance of the analysis of factors such as: investment cost, wastewater generation, level of method industrialization, degree of toxicity of the materials used, and accessibility of these materials.

Mahmoudi et al. (2019) also said that to develop and scale up the current photovoltaic panel recycling, it is necessary to reduce the gas emission and temperature during the delamination process. This could be done by choosing a proper mixing ratio for the etching process, decrease the use of chemicals and its wastes production, and achieve a high level of purification. However, changing from a pilot level to the industrial scale is imperative to ensure the recycling of all the amount of photovoltaic panel waste that will be generated and to prove economic feasibility (Cucchiella et al., 2015).The economic feasibility of the recycling requires collaborative action of all stakeholders in the industry. Deng et al. (2019) highlights that the government authorities should consider cost and regulation changes to discourage landfill of PV modules. Also, the manufacturers should include recycling viability into photovoltaic panels design and consider how to use second-life materials in their production systems.

\section{CONCLUSIONS}

The novelty of the present article was a statistical basis to compare the different parameters analyzed to improve the silver recovery from photovoltaic panels. The CCRD applications, as well as the use of samples of different brands and models of photovoltaic panels, are some of the highlights of this research.

Another main contribution of this work is the determination of the gravimetric composition of silicon photovoltaic panels, which was imperative in estimating the potential recovery of each component. According to the results, the fraction where the silver (photovoltaic cell) is found is superior in the photovoltaic panel composition when compared to the percentage of PCB from e-waste. Therefore, the importance of studying the metals recovery of photovoltaic cells is justified (material with lower heterogeneity than others e-waste, making the recycling easier).

Analysis of the photovoltaic cells, according to the results for leaching with $\mathrm{HNO}_{3}$, presented greater solubilization of silver, showing that up to $6.87 \mathrm{~kg}$ of silver can be recovered per ton of photovoltaic cells.

One of the findings of this research proved that there is no need to use high nitric acid concentrations for silver leaching, reducing reagent costs, and disposal. The solubilization of silver using nitric acid in a solid-liquid ratio of $0.05 \mathrm{~g} / \mathrm{mL}$ and $2 \mathrm{~h}$ of reaction time highlighted the following optimal parameters: temperature of $55^{\circ} \mathrm{C}$ and 2.3 $\mathrm{mol} / \mathrm{L}$ of $\mathrm{HNO}_{3}$ concentration. The statistical evaluation indicated that the temperature and the concentration of nitric acid are significant factors in the solubilization of silver.
Regarding the reaction time for silver solubilization, it was possible to solubilize $100 \%$ of silver in solution over 2 hours using the optimum parameters obtained.

The electrochemical process and the chemical precipitation with addition of $\mathrm{HCl}$ were shown to be equivalent in relation to the silver extraction, and for the electroprecipitation test, there was less contamination of lead in the precipitate.

The recycling route studied achieved the goal of recovering up to $99.98 \%$ of the silver from photovoltaic cells by combining processes involving acid leaching by nitric acid followed by electroprecipitation process.

\section{ACKNOWLEDGEMENTS}

This research was supported by the Fundação de Amparo à Pesquisa e Inovação do Espírito Santo (FAPES), Espírito Santo, Brazil (Process $n^{\circ}$ 68781369/2014 and Process $\left.n^{\circ} 83757392 / 2018\right)$. We would also like to thank Michael James Stablein of the University of Illinois Urbana-Champaign for his translation services and review of this paper.

\section{REFERENCES}

Apergis, I., \& Apergis, N. (2019). Silver prices and solar energy production. Environmental Science and Pollution Research, 26(9), 85258532. https://doi.org/10.1007/s11356-019-04357-1

Azeumo, M. F., Germana, C., Ippolito, N. M., Franco, M., Luigi, P., \& Settimio, S. (2019). Photovoltaic module recycling, a physical and a chemical recovery process. Solar Energy Materials and Solar Cells, 193, 314-319. https://doi.org/10.1016/J.SOLMAT.2019.01.035

Chen, W.-S., Chen, Y.-J., Yueh, K.-C., Cheng, C.-P., \& Chang, T.-C. (2020). Recovery of valuable metal from Photovoltaic solar cells through extraction. IOP Conference Series: Materials Science and Engineering, 720, 012007. https://doi.org/10.1088/1757899X/720/1/012007

Cucchiella, F., D’Adamo, I., Lenny Koh, S. C., \& Rosa, P. (2015). Recycling of WEEEs: An economic assessment of present and future ewaste streams. Renewable and Sustainable Energy Reviews, 51, 263-272. https://doi.org/10.1016/j.rser.2015.06.010

D’Adamo, I., Miliacca, M., \& Rosa, P. (2017). Economic Feasibility for Recycling of Waste Crystalline Silicon Photovoltaic Modules. International Journal of Photoenergy, 2017, 1-7. https://doi. org/10.1155/2017/4184676

Del Pero, F., Delogu, M., Berzi, L., \& Escamilla, M. (2019). Innovative device for mechanical treatment of End of Life photovoltaic panels: Technical and environmental analysis. Waste Management. https://doi.org/10.1016/j.wasman.2019.06.037

Deng, R., Chang, N. L., Ouyang, Z., \& Chong, C. M. (2019). A techno-economic review of silicon photovoltaic module recycling. Renewable and Sustainable Energy Reviews, 109(April), 532-550. https://doi. org/10.1016/j.rser.2019.04.020

Dias, P., Javimczik, S., Benevit, M., \& Veit, H. (2017). Recycling WEEE: Polymer characterization and pyrolysis study for waste of crystalline silicon photovoltaic modules. Waste Management, 60, 716722. https://doi.org/10.1016/J.WASMAN.2016.08.036

Dias, P., Javimczik, S., Benevit, M., Veit, H., \& Bernardes, A. M. (2016). Recycling WEEE: Extraction and concentration of silver from waste crystalline silicon photovoltaic modules. Waste Management, 57, 220-225. https://doi.org/10.1016/j.wasman.2016.03.016

Domínguez, A., \& Geyer, R. (2019). Photovoltaic waste assessment of major photovoltaic installations in the United States of America. Renewable Energy, 133, 1188-1200. https://doi.org/10.1016/j.renene.2018.08.063

Europe, S. P. (2018). Global Market Outlook for Solar Power 2018-2022. http://www.solarpowereurope.org/wp-content/uploads/2018/09/ Global-Market-Outlook-2018-2022.pdf 
Fiandra, V., Sannino, L., Andreozzi, C., Corcelli, F., \& Graditi, G. (2019). Silicon photovoltaic modules at end-of-life: Removal of polymeric layers and separation of materials. Waste Management, 87, 97-107. https://doi.org/10.1016/j.wasman.2019.02.004

Gangwar, P., Kumar, N. M., Singh, A. K., Jayakumar, A., \& Mathew, M. (2019). Solar photovoltaic tree and its end-of-life management using thermal and chemical treatments for material recovery. Case Studies in Thermal Engineering. https://doi.org/10.1016/j. csite.2019.100474

Hubau, A., Chagnes, A., Minier, M., Touzé, S., Chapron, S., \& Guezennec, A.-G. (2019). Recycling-oriented methodology to sample and characterize the metal composition of waste Printed Circuit Boards. Waste Management, 91, 62-71. https://doi.org/10.1016/J. WASMAN.2019.04.041

International Energy Agency. (2013). Trends 2013 in Photovoltaic Applications: photovoltaic power systems programme. http://www. iea-pvps.org/fileadmin/dam/public/report/statistics/FINAL_ TRENDS_v1.02.pdf

Joda, N. N., \& Rashchi, F. (2012). Recovery of ultra fine grained silver and copper from PC board scraps. Separation and Purification Technology, 92, 36-42. https://doi.org/10.1016/j.seppur.2012.03.022

Kang, S., Yoo, S., Lee, J., Boo, B., \& Ryu, H. (2012). Experimental in vestigations for recycling of silicon and glass from waste photovoltaic modules. Renewable Energy, 47, 152-159. https://doi. org/10.1016/j.renene.2012.04.030

Kasper, A. C., Berselli, G. B. T., Freitas, B. D., Tenório, J. A. S., Bernardes, A. M., \& Veit, H. M. (2011). Printed wiring boards for mobile phones: Characterization and recycling of copper. Waste $\mathrm{Ma}$ nagement, 31(12), 2536-2545. https://doi.org/10.1016/j.wasman.2011.08.013

Kuczyńska-Łażewska, A., Klugmann-Radziemska, E., Sobczak, Z., \& Klimczuk, T. (2018a). Recovery of silver metallization from damaged silicon cells. Solar Energy Materials and Solar Cells, 176, 190-195. https://doi.org/10.1016/J.SOLMAT.2017.12.004

Kuczyńska-Łażewska, A., Klugmann-Radziemska, E., Sobczak, Z., \& Klimczuk, T. (2018b). Recovery of silver metallization from damaged silicon cells. Solar Energy Materials and Solar Cells, 176, 190-195. https://doi.org/10.1016/j.solmat.2017.12.004

Kumar, S., \& Sarkan, B. (2013). Design for reliability with weibull analysis for photovoltaic modules. Int. J. Curr. Eng. Technol, 129-134.

Larsen, K. (2009). End-of-life PV: then what? Renewable Energy Focus. https://doi.org/10.1016/S1755-0084(09)70154-1

Latunussa, C. E. L., Ardente, F., Blengini, G. A., \& Mancini, L. (2016). Life Cycle Assessment of an innovative recycling process for crystalline silicon photovoltaic panels. Solar Energy Materials and Solar Cells, 156, 101-111. https://doi.org/10.1016/j.solmat.2016.03.020

Lee, C.-H., Chang, Y.-W., Popuri, S. R., Hung, C.-E., Liao, C.-H., Chang, J.-E., \& Chen, W.-S. (2018). Environmental Engineering and Management (Vol. 17, Issue 3). http://www.eemj.icpm.tuiasi.ro/;http:// www.eemj.eu

Lee, C. H., Hung, C. E., Tsai, S. L., Popuri, S. R., \& Liao, C. H. (2013) Resource recovery of scrap silicon solar battery cell. Waste Management and Research, 31(5), 518-524. https://doi. org/10.1177/0734242X13479433

Mahmoudi, S., Huda, N., Alavi, Z., Islam, M. T., \& Behnia, M. (2019). End-of-life photovoltaic modules: A systematic quantitative literature review. In Resources, Conservation and Recycling. https://doi. org/10.1016/j.resconrec.2019.03.018

Monier, V., \& Hestin, M. (2011). Study on Photovoltaic panels supplementing the impact assessment for a recast of the WEEE directive. In Bio Intelligence Service (Issue April).

Motta, V. C. N. da. (2018). Extração de cobre de placas de circuito impresso de tablets por lixiviação ácida e precipitação seletiva. Federal University of Espírito Santo.

Nevala, S. M., Hamuyuni, J., Junnila, T., Sirviö, T., Eisert, S., Wilson, B. P., Serna-Guerrero, R., \& Lundström, M. (2019). Electro-hydraulic fragmentation vs conventional crushing of photovoltaic panels Impact on recycling. Waste Management, 87, 43-50. https://doi. org/10.1016/j.wasman.2019.01.039

Olson, C.L.; Geerligs, L.J.; Goris, M.J.A.A.; Bennett, I.J.; Clyncke, J. (2013). Current and future priorites for mass and material in silicon PV moduloe. ECN Solar Energy, 4629-4633.
Padoan, F. C. S. M., Altimari, P., \& Pagnanelli, F. (2019). Recycling of end of life photovoltaic panels: A chemical prospective on process development. Solar Energy, 177(December 2018), 746-761. https:// doi.org/10.1016/j.solener.2018.12.003

Paiano, A. (2015). Photovoltaic waste assessment in Italy. Renewable and Sustainable Energy Reviews, 41, 99-112. https://doi. org/10.1016/j.rser.2014.07.208

Prado, P. F. A., \& Ruotolo, L. A. M. (2016). Silver recovery from simulated photographic baths by electrochemical deposition avoiding Ag2S formation. Journal of Environmental Chemical Engineering, 4(3), 3283-3292. https://doi.org/10.1016/j.jece.2016.06.035

Raju, T., Chung, S. J., \& Moon, I. S. (2009). Electrochemical recovery of silver from waste aqueous $\mathrm{Ag}(\mathrm{I}) / \mathrm{Ag}(\mathrm{II})$ redox mediator solution used in mediated electro oxidation process. Korean Journal of Chemical Engineering, 26(4), 1053-1057. https://doi.org/10.2478/ s11814-009-0175-X

Rebelllo, R. Z. (2018). Recuperação de ouro e prata de lâmpadas de LED inservíveis por lixiviação em tiouréia. Federal University of Espírito Santo

Rojas, C. E. B., \& Martins, A. H. (2010). Reciclagem de sucata de jóias para a recuperação hidrometalúrgica de ouro e prata. Metalurgia \& Materiais, 1-7

Santos, J. D., \& Alonso-García, M. C. (2018). Projection of the photovoltaic waste in Spain until 2050. Journal of Cleaner Production, 196 1613-1628. https://doi.org/10.1016/j.jclepro.2018.05.252

Savvilotidou, V., \& Gidarakos, E. (2019). Pre-concentration and recovery of silver and indium from crystalline silicon and copper indium selenide photovoltaic panels. Journal of Cleaner Production, $x x x x$ 119440. https://doi.org/10.1016/j.jclepro.2019.119440

Shin, J., Park, J., \& Park, N. (2017). A method to recycle silicon wafer from end-of-life photovoltaic module and solar panels by using recycled silicon wafers. Solar Energy Materials and Solar Cells, 162(September 2016), 1-6. https://doi.org/10.1016/j.solmat.2016.12.038

Sica, D., Malandrino, O., Supino, S., Testa, M., \& Lucchetti, M. C. (2018) Management of end-of-life photovoltaic panels as a step towards a circular economy. Renewable and Sustainable Energy Reviews, 82, 2934-2945. https://doi.org/10.1016/J.RSER.2017.10.039

Song, B. P., Zhang, M. Y., Fan, Y., Jiang, L., Kang, J., Gou, T. T., Zhang, C. L., Yang, N., Zhang, G. J., \& Zhou, X. (2020). Recycling experimental investigation on end of life photovoltaic panels by application of high voltage fragmentation. Waste Management, 101, 180-187. https://doi.org/10.1016/j.wasman.2019.10.015

Tammaro, M., Salluzzo, A., Rimauro, J., Schiavo, S., \& Manzo, S. (2016). Experimental investigation to evaluate the potential environmental hazards of photovoltaic panels. Journal of Hazardous Materials, 306, 395-405. https://doi.org/10.1016/J.JHAZMAT.2015.12.018

Tao, J., \& Yu, S. (2015). Review on feasible recycling pathways and technologies of solar photovoltaic modules. Solar Energy Materials and Solar Cells, 141, 108-124. https://doi.org/10.1016/j.solmat.2015.05.005

U.S. Geological Survey. (2015). Mineral Commodity Summaries 2015 US Geological Survey, 196. https://doi.org/10.3133/70140094

Vogel, A. I. (1981). Quimica analitica qualitativa (5th ed.). Ed. Mestre Jou. https://books.google.com.br/books?id=VJ02QwAACAAJ

Weckend, S., Wade, A., \& Heath, G. (2016). End of Life Management: Solar Photovoltaic Panels. Paris, France: International Energy Agency (IEA). https://doi.org/10.2172/1561525

Yang, E.-H., Lee, J.-K., Lee, J.-S., Ahn, Y.-S., Kang, G.-H., \& Cho, C.-H (2017). Environmentally friendly recovery of $\mathrm{Ag}$ from end-of-life c-Si solar cell using organic acid and its electrochemical purification. Hydrometallurgy, 167, 129-133. https://doi.org/10.1016/j. hydromet.2016.11.005

Yousef, S., Tatariants, M., Denafas, J., Makarevicius, V., Lukošiūtè, S.-I., \& Kruopienè, J. (2019). Sustainable industrial technology for recovery of Al nanocrystals, Si micro-particles and Ag from solar cell wafer production waste. Solar Energy Materials and Solar Cells, 191, 493-501. https://doi.org/10.1016/J.SOLMAT.2018.12.008

Zhang, L., \& Xu, Z. (2016). A review of current progress of recycling technologies for metals from waste electrical and electronic equipment. Journal of Cleaner Production, 127, 19-36. https://doi. org/10.1016/j.jclepro.2016.04.004 